\begin{tabular}{cc|c}
\hline Tar. Bil. Der. & Journal of Agricultural Sciences \\
& $\begin{array}{c}\text { Dergi web sayfası: } \\
\text { www.agri.ankara.edu.tr/dergi }\end{array}$ & Journal homepage: \\
& www.agri.ankara.edu.tr/journal
\end{tabular}

\title{
Döl Tutma Problemi Olan Holştayn Irkı Sığırlarda Sitogenetik ve Moleküler Genetik Taramalar
}

\author{
Korhan ARSLAN ${ }^{\text {a }}$, Fadime ÖZDEMİR ${ }^{\text {a }}$ Esma Gamze İLGAR ${ }^{\text {a }}$, Bilal AKYÜZ ${ }^{\mathrm{a}}$ \\ ${ }^{a}$ Erciyes Üniversitesi, Veteriner Fakültesi, Genetik Anabilim Dall, 38039, Kayseri, TÜRKIYE
}

\section{ESER BİLGISI}

Araștırma Makalesi

DOI: 10.1501/Tarimbil_0000001395

Sorumlu Yazar: Korhan ARSLAN, E-posta: korhanarslan@erciyes.edu.tr, Tel: +90 (352) 2076666

Geliş Tarihi: 02 Aralık 2014, Düzeltmelerin Gelişi: 25 Mayıs 2015, Kabul: 25 Mayıs 2015

\section{ÖZET}

Sı ̆̆ır yetiştiriciliğinde repeat breeder sendromu olarak adlandırılan döl tutma problemi önemli bir sorundur. Holştayn ırkı sığırlarda bu problemin ortaya çıkmasında bakım-beslemenin yanı sıra Robertsonian translokasyon ve faktör XI yetmezliği (FXID) olarak adlandırılan genetik bozukluklarında rolü olduğu düşünülmektedir. Bu çalışmada Kayseri ilinde bir çiftlikte bulunan repeat breederlı Holştayn ırkı ineklerde Robertsonian translokasyon ve FXID varlığının araştırılması amaçlanmıştır. Yapılan çalışmada, repeat breeder tanısı konan 62 baş Holştayn ırkı inek incelenmiştir. Kromozomal inceleme sonucunda 62 hayvanın 58'inin normal karyotip ( $2 \mathrm{n}=60$ diploid), dördünün ise en sik görülen 1;29'dan farklı dört tip Robertsonian translokasyon [rob $(1 ; 21)$, rob $(23 ; 26)$, rob $(24 ; 26)$, rob (26;29)] profiline sahip olduğu saptanmıştır. Yapılan PCR analizi sonucunda, incelenen 62 örneğin hiçbirinde FXID'e neden olan mutasyona ait bant görüntüsü gözlenmemiştir. Çalışma sonunda, döl tutma problemi bulunan sı̆̆ırlarda sitogenetik ve moleküler genetik taramaların yapılmasının kalıtsal nedenlerle gelişen repeat breeder sendromu gösteren damızlık adayların belirlenerek damızlık dışı bırakılmasına ve bu sayede özellikle damızlık yetiştiren işletmeler için çözüm yollarının aranmasına katkı sağlayacağı düşünülmüştür.

Anahtar Kelimeler: FXID; Holştayn; Repeat breeder; Robertsonian translokasyon

\section{Cytogenetic and Molecular Genetic Screening in Holstein Cattle Breed which Showing Repeat Breeding Problems}

\author{
ARTICLE INFO \\ Research Article \\ Corresponding Author: Korhan ARSLAN, E-mail: korhanarslan@erciyes.edu.tr, Tel: +90 (352) 2076666 \\ Received: 02 December 2014, Received in Revised Form: 25 May 2015, Accepted: 25 May 2015
}

\begin{abstract}
The infertility problem named Repeat Breeder Syndrome is an important issue in cattle breeding. Beside maintenance and feed techniques, some genetic disorders such as Robertsonian Translocation and factor XI deficiency (FXID) are thought to be involved some problems in Holstein cattle. In this study, it was aimed to investigate the presence of Robertsonian Translocation and FXID in repeat breeder Holstein cows which grown a farm that located in the province
\end{abstract}


of Kayseri. In the study 62 female Holstein cattle with Repeat Breeder Syndrome were examined. Chromosomal examination results indicated that 58 of 62 cows had a normal karyotype ( $2 n=60$ diploid) and four had different of Robertsonian translocation $[\operatorname{Rob}(1,21), \operatorname{rob}(23,26), \operatorname{Rob}(24,26), \operatorname{Rob}(26,29)]$ profiles. None of the 62 cows was displayed the band of mutation which is the cause of FXID. As a result of the study it was determined molecular and cytogenetical screening of cows with a fertility problem could contribute to understand the reasons of repeat breeder syndrome and could be useful for the breeders to select the female breeding candidates and finding the solution for this problem.

Keywords: FXID; Holstein; Repeat breeder; Robertsonian translocation

(C) Ankara Üniversitesi Ziraat Fakültesi

\section{Giriş}

Döl verimi, süt sığırı yetiştiriciliği yapan bir işletmenin ekonomik yapısını etkileyen önemli bir verim özelliğidir. Bu sebeple infertilite günümüzde süt sığırı yetiştiriciliğinde mastitisle birlikte en önemli sorunlardan biridir. Sığır yetiştiriciliğinde döl verimini olumsuz yönde etkileyerek, işletme için önemli ekonomik kayılara neden olan durumlardan biride "repeat breeder" olarak adlandırılan döl tutma problemidir. Repeat breeder terimi; en az bir doğum yapmış, düzenli seksüel siklus gösteren, genital organlarda klinik muayenelerle herhangi bir patolojik bulgu ve anomali görülmemesine rağmen üç veya daha fazla sayıda tohumlandığı halde gebe kalmayan ve tohumlamayı takiben bir sonraki östrus periyodunda kızgınlık gösteren sığırlar için kullanılmaktadır (Alaçam 1997; Bage et al 2002).

Sığırlarda fertilite üzerinde direkt etkiye sahip genetik tabanlı patolojilerden biri kromozom sayıs1 ve yapısındaki değişiklikler olarak tanımlanan kromozomal mutasyonlardır (El-Bayomi et al 2011). Kromozomal mutasyonlar üreme sisteminde görülen fonksiyonel ve anatomik bozukluklara sebep olur (Iannuzzi et al 2001). Sığırlarda fertilite bozukluklarına neden olan Robertsonian translokasyon, mayoz bölünme esnasında kendiliğinden, kimyasal veya radyoaktif mutajenlerin etkisi sonucu (Klug \& Cummings 2003) kısa kolları kaybolmuş olan iki akrosentrik kromozomun uç uca birleşmesi ile karyotipte markır bir kromozomun ortaya çıkması ile karakterizedir (Chaves et al 2000; Di Meo et al 2006). Sitogenetik analizler ile damızlı adaylarının kromozomal profilinin ortaya konulmasının kromozomal yönden mutasyonlu dişilerin belirlenerek yetiştirme dışı bırakılması ile işletmelerin ekonomik kazanım sağlanabileceği bildirilmektedir (Pinton et al 1997; Molteni et al 2005).

Faktör XI yetmezliği (FXID), Holştayn sığır ırkında heterozigot durumda dahi infertiliteye sebep olabildiği bildirilen kalıtsal bir hastalıktır (Kolgeci et al 2013). FXID taşıyıcılarında hastalığa özel klinik semptomlar görülmediği için hastalığın teşhisinde en etkili yöntemin Polimeraz Zincir Reaksiyonu (PCR) olduğu bildirilmiştir (Citek et al 2006; Kolgeci et al 2013).

Kalıtsal hastalıklar çiftlik hayvanları yetiştiriciliğinde damızlıkların üreme gücünde problemler oluşturmanın yanı sıra doğan yavruların yaşama gücünü düşürerek de işletmelerde önemli ekonomik kayıplara sebep olmaktadır (Wathes 1992). Yetiştirme programlarının başarısında, yetiştirilmesi planlanan rrklarda gen ve kromozom düzeyinde en yaygın görülen kalıtsal hastalıklar yönünden damızlık adayların taranması önemlidir.

Yapılan çalışmada repeat breeder'lı Holştayn ineklerde Robertsonian translokasyonu ve FXID'e neden olan mutasyonun varlığı/yokluğunun araştırılması amaçlanmıştır.

\section{Materyal ve Yöntem}

Çalışmanın hayvan materyalini, Kayseri ilindeki bir süt sığırcılığı işletmesinde bulunan, aralarında akrabalık ilişkisi olmayan, en az bir kez doğum yapmış ancak, işletme kayıtlarına göre hastalık geçmişi olmamasına rağmen gebe kalmadığı için işletme tarafindan repeat breeder olarak kabul edilerek kesime sevk edilmiş 62 baş dişi Holştayn 
sığır oluşturmuştur. Çalışılan sığırlarda her bir hayvan için sitogenetik analiz olarak, heparinli tüplere alınan kanlardan, her bir hayvan için 50 metafaz alanının incelendiği GTG-bantlama yapılmıştır. Faktör XI yetmezliğinin araştırılmasında EDTA'lı tüplere $V$. jugularis'ten alınan kanlardan elde edilen DNA'lar kullanılarak PCR analizi yapılmıştır.

Kromozom analizi için Pinton et al (1997) tarafından önerilen yöntem modifiye edilerek uygulanmıştır. $\mathrm{Bu}$ amaçla $1 \mathrm{~mL}$ penisilin, $20 \mathrm{~mL}$ fetal bovine serum ve $2.5 \mathrm{~mL}$ fitohemaglutinin içeren RPMI 1640 ortamı içine heparinize periferal kanlar eklenerek hazırlanan karışım \% $5 \mathrm{CO}_{2}{ }^{\prime} l i$ etüvde $37^{\circ} \mathrm{C}$ 'de 72 saat kültüre alınmıştır. Etüvdeki tüplere 71 . saatte $75 \mu \mathrm{L}$ kolşisin ilave edilerek mitoz bölünme bloke edilmiştir.

Kültür sonrasında örnekler GTG-bantlama (Seabright 1971) yöntemi ile boyanarak her preparattaki 50 metafaz alanı "Cyt Vision Version 7.2" (Applied Imaging CytoVision ${ }^{\mathrm{TM}}$ Imaging System) programı ile analiz edilerek örnekler Robertsonian translokasyon varlı̆̆1/yokluğu yönünden değerlendirilmiştir.

Moleküler analiziçin örneklere ait DNA'lar fenolkloroform yöntemi ile izole edilmiştir (Sambrook et al 1989). İncelenen örneklerde FXID'e neden olan mutant alleli belirlemek için yapılan PCR işleminde forward: 5' - CCC ACT GGC TAG GAA TCG TT3'; reverse: 5' - CAA GGC AAT GTC ATA TCC AC -3', olacak şekilde bir primer seti kullanılmıştır.

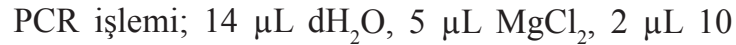
x PCR buffer, $1.1 \mu \mathrm{L}$ dNTP, $0.4 \mu \mathrm{L}$ (20 nmol) primer, $0.2 \mu \mathrm{L}$ Taq polimeraz $\left(5 \mathrm{U}_{\mu} \mathrm{L}^{-1}\right)$ ve $3 \mu \mathrm{L}$ DNA eklenerek hazırlanan karışımla yapılmıştır. Hazırlanan karışımın başlangıçta $95^{\circ} \mathrm{C}$ ' de 10 dakika tutulmasını takiben her bir döngüsü; $95{ }^{\circ} \mathrm{C}$ 'de 30 saniye, $55^{\circ} \mathrm{C}^{\prime}$ de 1 dakika, $72{ }^{\circ} \mathrm{C}$ 'de 30 saniye olacak şekilde 34 döngü olarak yapılmıştır. PCR işlemi son döngünün bitiminden sonra örnekler $72{ }^{\circ} \mathrm{C}$ 'de 10 dakika tutularak tamamlanmıştır. İncelenen bireylerin FXID yönünden genotiplendirilmesi ve elde edilen PCR ürünlerinin değerlendirilmesi $\%$ 2'lik agaroz jel elektroforezi ile yapılmıştır.

\section{Bulgular ve Tartışma}

Yapılan kromozomal inceleme sonucunda, 62 Holştayn ineğin 58'inin normal karyotipe $(2 \mathrm{n}=$ 60 diploid) sahip olduğu, dört hayvanın ise farklı Robertsonian translokasyon [rob $(1 ; 21)$, rob $(23 ; 26)$, rob $(24 ; 26)$, rob (26;29)] profillerine sahip oldukları belirlenmiştir (Şekil 1, 2, 3, 4 ).

Yapılan PCR reaksiyonu sonunda, taşıyıcı bireyde 244 ve 320 bp'lik iki bant, homozigot normal bireylerde 244 bp'lik tek bant, homozigot hasta bireylerde ise 320 bp'lik tek bandın görülmesi beklenmiştir (Şekil 5). Ancak incelenen 62 örneğin hiçbirisinin homozigot veya heterozigot FXID'e neden olan mutasyona sahip olmadıkları gözlenmiştir.

Sığır yetiştiriciliğinde, tohumlama sonrası gebeliğin şekillenmemesi ve erken embriyonik ölümler yılda bir yavru alınmasını engelleyerek işletme için önemli ekonomik kayılplara neden olmaktadır (Rubes et al 1996). Üç tohumlama sonunda gebeliğin şekillenmediği repeat breeder sendromu süt sığırı yetiştiriciliğinde oldukça önemli bir sorundur. Bu sendromun gelişmesinde beslenme ve çevre sıcaklığı gibi çevresel faktörlerin yanı sıra FXID olarak adlandırılan bir gen mutasyonu ve Robertsonian translokasyon gibi bazı kromozomal mutasyonların etkili olduğu bildirilmiştir (Wathes 1992; Joerg et al 2001; Gustafsson \& Emanuelson 2002; Akyüz 2013). Repeat breeder'ın gelişmesinde etkili olan bakım-besleme gibi çevresel faktörlerin minimize edilebilmesi için çalışmanın hayvan materyalinin aynı işletmeden temin edilmesi yoluna gidilmiştir. Çalışma materyali seçilirken işletmenin döl verim kayıtları dikkate alınarak genital sistem hastalıkları yönünden daha önce herhangi bir hastalık geçirmeyen hayvanlar seçilmiştir.

Genetik kusurlar içerisinde önemli bir yer tutan kromozomal bozuklukların sığırlarda döl tutma problemlerine sebep olduğu bildirilmiştir (King 1990). Sayısal ve yapısal kromozom anomalilerinin embriyoda anormal gelişmeye veya gebeliğin ilk üç aylık döneminde embriyonel ölüme neden olabildiği bildirilmiştir (Joerg et al 2001). Düve ve ineklerde embriyoların \% 20'sinin gebeliğin ilk 


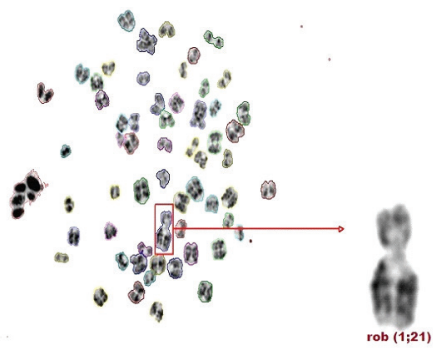

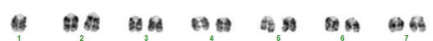

क्षे

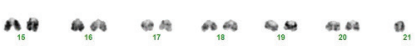

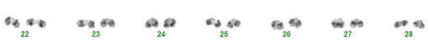

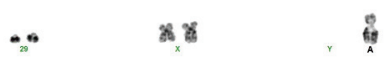

Şekil 1- Rob $(1 ; 21)$ translokasyon metafaz ve karyotip görüntüsü

Figure 1- Rob (1;21) translocation metaphase and karyotype image

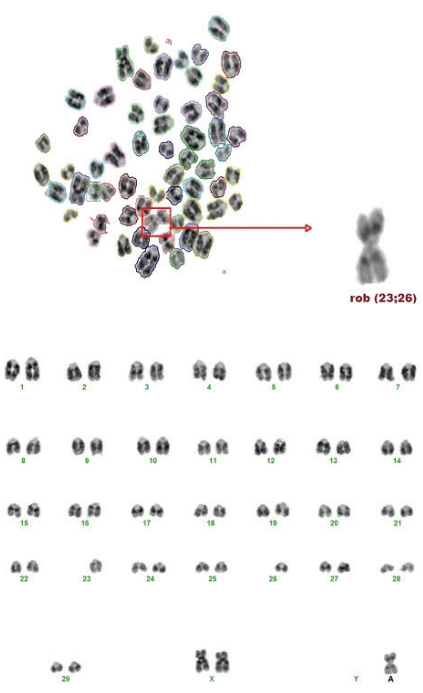

Şekil 2- Rob $(23 ; 26)$ translokasyon metafaz ve karyotip görüntüsü

Figure 2- Rob $(23 ; 26)$ translocation metaphase and karyotype image

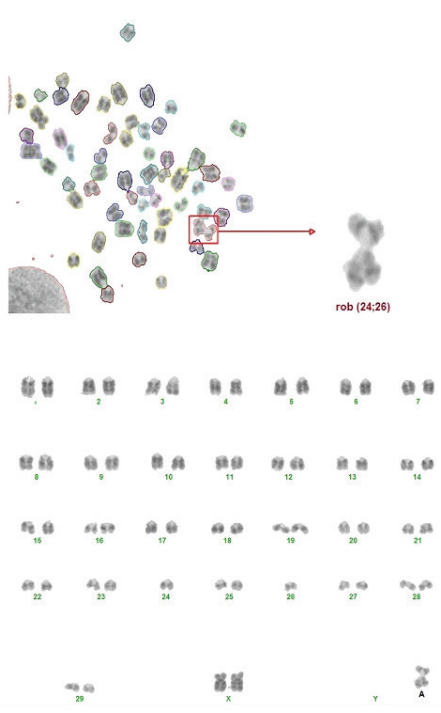

Şekil 3- Rob (24;26) translokasyon metafaz ve karyotip görüntüsü

Figure 3- Rob (24;26) translocation metaphase and karyotype image
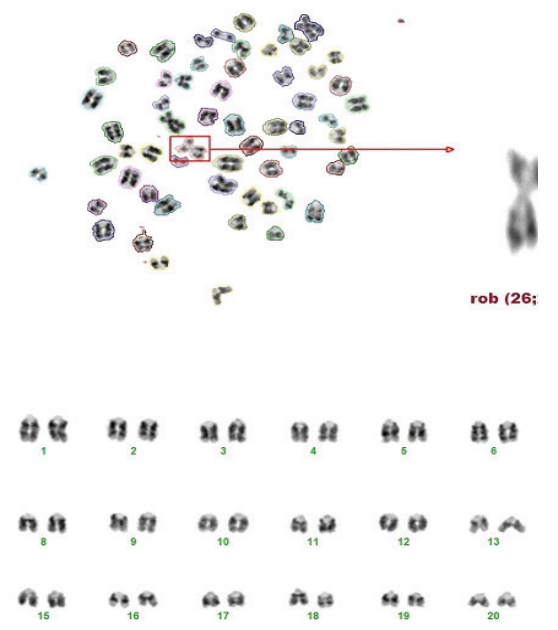

Şekil 4- Rob $(26 ; 29)$ translokasyon metafaz ve karyotip görüntüsü

Figure 4- Rob (26;29) translocation metaphase and karyotype image 


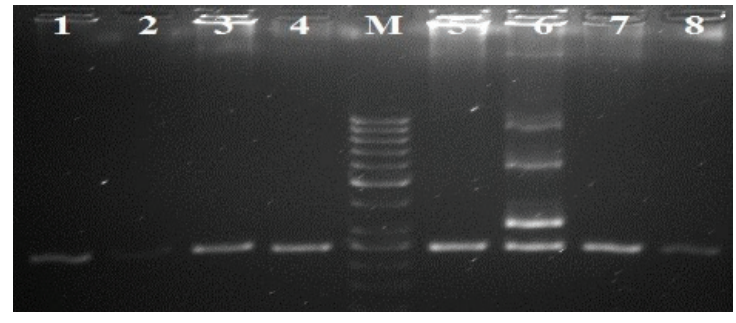

Şekil 5- FXID yönünden yapılan PCR sonuçlarının $\%$ 2'lik agaroz jel görüntüsü; $M, 50$ bç'lik DNA merdiveni; 5, homozigot normal kontrol (244 bç); 6, heterozigot kontrol (244 bç, 320 bç); 1, 2, 3, 4, 7 ve 8 homozigot normal bireyler

Figure 5- PCR results of FXID on 2\% agarose gel image; $M, 50$ bpDNA Ladder; 5, homozygous control (244 bp); 6, heterozygous control (244 bp, 320 bp); 1, 2, 3, 4, 7 ve 8 homozygous normal subjects

12-16. günleri arasında dejenere olabildiği, ancak repeat breeder sendromu gösteren hayvanlarda ise embriyonik kayıpların gebeliğin 4-7. günleri arasında şekillendiği bildirilmiştir (Seguin et al 2000).

Gerçek sığır (Bos taurus) karyotipi 29 çift akrosentrik otozomal kromozom ve bir çift submetasentrik gonozomal kromozom olmak üzere toplam 30 çift kromozomdan oluşmaktadır (Chaves et al 2000). Akrosentrik kromozomlarda görülen kromozom füzyonu sonucu oluşan Robertsonian translokasyon sığırlarda en sık görülen kromozomal anomalilerinden biri olarak bildirilmektedir (Joerg et al 1999). Siğırda tanımlanan ilk Robertsonian translokasyonu, tek heterokromatin bloğa sahip 1. ve 29. kromozomlar arasındaki sentrik füzyon kaynaklı rob $(1 ; 29)$ translokasyonudur (Parvatti et al 1985). Heterozigot Robertsonian taşıyıcıllığ1 görülen dişi hayvanlar genellikle normal fenotipe sahiptir. Ancak bu bireylerde erken embriyonik ölüm şekillenmesinden dolayı fertilitelerinde $\% 3$ ile \% 5 arasında bir azalma olduğu bildirilmiştir (Roberts 1986). Robertsonian translokasyon taşıyıcıs1 hayvanlarda fertilite problemlerinin normal hayvanlara göre daha fazla görüldüğü ve translokasyonun jenerasyonlar arasında segrege olabilen özellikte olduğu bildirilmiştir (Pinton et al 1997; Nicolae 2007). Belirtilen sebeplerle bu kromozomal anomaliyi taşıyan hayvanların belirlenerek yetiştirme dışı bırakılmasının yetiştiricilik açısından önemli bir kazanım olabileceği ifade edilmektedir (De Lorenzi et al 2008). Yapılan bu çalışmada Robertsonian translokasyon varlığının araştırılmasında tabloyu kesin olarak ortaya koyan, ayn zamanda benzer amaçla kullanılan Floresan Insituhibridizasyon (FISH) yöntemi gibi daha pahalı yöntemlere göre ucuzluğu nedeniyle avantajlı olan GTG-bantlama yöntemi kullanılmıştır.

Sığırlarda Robertsonian translokasyon tiplerinin tespit edilmesi ile ilgili yapılan farklı çalışmalarda İngiliz etçi sığır ırkları, Holştayn, Jersey, Normande sığır irklarında rob $(1 ; 29)$ translokasyon tipinin görülmediği ortaya konmuştur (Seguin et al 2000; De Luca et al 2002). Miyake et al (1991) yaptıkları çalışmada sığırlarda rob $(1 ; 21)$ translokasyonu; Iannuzzi et al (2001) yaptıkları çalışma sonucu sığırlarda rob $(26 ; 29)$ varlığını bildirmişlerdir.

Kayseri ilinde yetiştirilen 62 baş repeat breederlı Holştayn ineğin incelendiği bu çalışmada da yapılan kromozomal tarama neticesinde repeat breeder gösteren hayvanların \% 6'sının farklı kromozomal yapıya sahip olduğu gözlenmiştir. Sitogenetik taramalarda rob $(1 ; 29)$ translokasyona rastlanılmamış ancak, incelenen hayvanların dördünde, dört farklı Robertsonian translokasyonunun varlığı belirlenmiştir. Yapılan literatür taramasında, bu çalışmada belirlenen rob $(1 ; 21)$, rob $(23 ; 26)$, rob $(24 ; 26)$, rob $(26 ; 29)$ translokasyonlara yaygın olarak rastlanılmadığ gözlenmiş, dolayısı ile görülen bu translokasyonların nadir tipler olduğu düşünülmüştür. Çalışma bulguları neticesinde, sığır yetiştiriciliğinde önemli bir döl verimi problemi olan repeat breeder sendromunun ortaya çıkmasına neden olan faktörlerin daha kesin olarak belirlenebilmesi için sitogenetik taramaların da göz önünde bulundurulmasının gerekli olduğu düşünülmüştür.

Holştayn sığır ırkında görülen bir nokta mutasyon, kan pıhtılaşma faktörlerinden XI yetmezliğine (FXID) neden olarak, bu 
mutasyon yönünden heterozigot bireylerde dahi döl tutma problemlerine neden olarak repeat breeder sendromunun gelişmesine etkisi olduğu bildirilmiştir (Ghanem et al 2005). Ghanem et al (2005) tarafindan yapılan çalışmada, döl tutma problemi olan hayvanlar arasinda FXID prevalansının \% 2.5 olduğunu bildirilmiştir. Benzer şekilde Polonya'da farklı çiftliklerden toplanan ve 28 'inde repeat breeder, 9'unda ise tekrarlayan mastitis gösteren bireylerinde bulunduğu rastgele 140 baş Holştayn inek seçilerek FXID yönünden incelenmiştir. Çalışma sonunda rastgele seçilen ve herhangi bir problemi bulunmayan 103 baş örnekte FXID alleline rastlanılmamışken, repeat breederlı 28 örneğin bir tanesinin FXID taşıyıcı olduğu belirlenmiştir (Gurgul et al 2009). Benzer şekilde Akyüz et al (2012) tarafindan normal fertilite gösteren 118 baş ve repeat breeder senromu gösteren 43 baş toplam 161 baş Holştayn ineğin incelendiği bir çalışmada FXID prevalansının normal fertilite gösteren grupta $\% 0.85$ olarak bulunmuşken, repeat breeder sendromu gösteren grupta \% 2.33 olarak bulunmuştur.

\section{Sonuç}

Repeat breeder sendromu gösteren 62 baş Holştayn ineğin incelendiği bu çalışmada elde edilen sonuçlar, farklı Robertsonian translokasyon tiplerinin repeat breeder sendromu gösteren Holştayn ırkı ineklerde bulunma şansının olabileceğini göstermiştir. Çalışmada incelenen repeat breeder tanısı konulmuş örneklerde FXID'e neden olan mutasyona rastlanılmamıştır. Ancak repeat breeder sendromunun gerçek sebebinin belirlenmesi çalışmalarında daha önce yapılan ve FXID ile repeat breeder sendromu arasında ilişki olabileceğini bildiren çalışmaların sonuçlarının (Ghanem et al 2005; Gurgul et al 2009; Akyüz et al 2012) dikkate alınması gerektiği düşünülmektedir. Ayrıca, gerek erkek gerekse dişi damızlık adaylarının farklı Robertsonian translokasyon tipleri ve FXID yönünden değerlendirilmelerinin yetiştiriciler için avantajlı olacağı düşünülmektedir. Daha kesin sonuçlar için daha çok örneğin inceleneceği çalışmalar planlanmalıdır.
$\mathrm{Bu}$ çalışma sonuçlarına göre süt sığırı yetiştiriciliğinde, oluşumunda birçok faktörün etkili olduğu repeat breeder sendromunun sebebine yönelik çalışmalarda genetik faktörlerinde düşünülmesinin gerekli olduğu sonucuna varılmıştır. Dolayısıyla damızlık adayı boğaların seçimi yanında, döl tutma problemi olan dişilerde de sitogenetik ve moleküler genetik tanı yöntemleri kullanılarak genetik sebeplerden kaynaklanan repeat breeder'in elimine edilmesi düşünülmelidir.

\section{Kaynaklar}

Akyüz B (2013). Türkiye'deki iki farklı işletmede yetiştirilen Holştayn boğalarda Faktör XI Yetmezliği (FXID) allel frekansinın belirlenmesi. Kafkas Üniversitesi Veteriner Fakültesi Dergisi 19: 127-131

Akyüz B, Sarı̈özan S \& Bayram D (2012). Factor XI mutation in normally fertile and repeat breeding Holstein cows in the Middle Anatolian region of Turkey: A financial approach. Animal Production Science 52: 1042-1045

Alaçam E (1997). Büyük Ruminantlarda İnfertilite. Evcil Hayvanlarda Doğum ve Infertilite. Medisan Yayınevi, Ankara. s. 269-294

Bage R, Gustafsson H, Larsson B, Forsberg M \& Rodriguez-Martinez H (2002). Repeat breeding in dairy heifers: Follicular dynamics and estrous cycle characteristics in relation to sexual hormone patterns. Theriogenology 57: 2257-2269

Chaves R, Heslop-Harrison J S \& Guedes-Pinto H (2000). Centromeric heterochromatin in the cattle rob $(1 ; 29)$ translocation: $\alpha$-satellite I sequences, in-situ MspI digestion patterns, chromomycin staining and C-bands. Chromosome Research 8: 621-626

Citek J, Rehout V, Hajkova J \& Pavkova J (2006). Monitoring of the genetic health of cattle in the Czech Republic. Veterinary Medicina Czech 51: 333-339

De Lorenzi L, De Giovanni A, Molteni L, Denis C, Eggen A \& Parma P (2008). Characterization of a balanced reciprocal translocation, $\operatorname{rcp}(9 ; 11)(\mathrm{q} 27 ; \mathrm{q} 11)$ in cattle. Cytogenetic Genome Research 119: 231-234

De Luca J C, Zufriategui L, Picco S J, Ripoli M V, Giovambattista G, Rojas F V \& Dulout F N (2002). Incidence of $1 / 29$ translocation in Bolivian Creole and Brahman Yacumeno cattle. Theriogenology 58: 12731281 
Di Meo G P, Perucatti A, Chaves R, Adega F, De Lorenzi L, Molteni L, De Giovanni A, Incarnato D, GuedesPinto H, Eggen A \& Iannuzzi L (2006). Cattle rob $(1 ; 29)$ originating from complex chromosome rearrangements as revealed by both banding and FISH-mapping techniques. Chromosome Research 14: $649-655$

El-Bayomi K M, El-Arab I E \& Zaglool A W (2011). Cytogenetic analysis related to some infertility problems in cattle. Global Veterinaria 7: 323-329

Ghanem M E, Nishibori M, Nakao T, Nakatani K \& Akita M (2005). Factor XI mutation in a Holstein cow with repeat breeding in Japan. The Journal of Veterinary Medical Science 67: 713-715

Gurgul A, Rubis D \& Slota E (2009). Identification of carriers of the mutation causing coagulation factor XI deficiency in Polish Holstein-Friesian cattle. Journal of Applied Genetics 50: 149-152

Gustafsson H \& Emanuelson U (2002). Characterisation of the repeat breeding syndrome in Swedish dairy cattle. Acta Veterinaria Scandinavica 43: 115-125

Iannuzzi L, Molteni L, Di Meo G P, Perucatti A, Lorenzi L, Incarnato D, De Giovanni A, Succi G \& Gustavsson I (2001). A new balanced autosomal reciprocal translocation in cattle revealed by banding techniques and human-painting probes. Cytogenetics and Cell Genetics 94: 225-228

Joerg H, Kneubuehler J, Steiger D \& Stranzinger G (1999). Progenytesting of heterozygotecarriers of the Robertsonian translocation 1/29 in Boridae. Animal Biotechnology 10: 127-131

Joerg H, Garner D, Rieder S, Suwattana D \& Stranzinger G (2001). Molecular genetic characterization of Robertsonian translocations in cattle. Journal of Animal Breeding and Genetics 118: 371-377

King W A (1990). Cromosome abnormalities and pregnancy failure in domestic animals. Advances in Veterinary Science \& Comparative Medicine 34: 229250

Klug W S \& Cummings M R (2003). Genetik Kavramlar. Ankara, Palme Yayıncılık

Kolgeci S, Kolgeci J, Azemi M, Shala R, Dakas A \& Sopjani M (2013). Reproductive risk of the silent carrier of Robertsonian translocation. Medical Archives 67: 56-59
Miyake Y, Murakami R K \& Kaneda Y (1991). Inheritance of the Robertsonian translocation $(1 / 21)$ in the Holstein-Friesian cattle. I. Chromosome analysis. Journal of Veterinary Medical Science 53: 113-116

Molteni L, Meggiolaro D, De Giovanni Macchi A, De Lorenzi L, Crepaldi P, Stacchezzini S, Cremonesi F \& Ferrara F (2005). Fertility of cryoconserved sperm in three bulls with different Robertsonian translocations. Animal Reproduction Science 86: 27-36

Nicolae I (2007). The role of cytogenetics in the genetic improvement of cattle. In: 3rd Joint Meeting of the Network of Universities and Research Institutions of Animal Science of the South Eastern European Countries, 10-12 Feb, Thessaloniki

Parvatti K, Basrur P K \& Bongso A T (1985). Amniocentesis for prenatal detection of sex and cytogenetic defects in cattle. In: DA Morrow (Ed), Current Therapy (Theriogenology), W B Saunders, Philadelphia, pp. 1185-1189

Pinton A, Ducos A, Berland H M, Seguela A, Blanc M F, Darre A, Mimar S \& Darre R (1997). A new Robertsonian translocation in Holstein-Friesian cattle. Genetics Selection Evolution 29: 523-526

Roberts S J (1986). Gestation period embryology, fetal membranes and placenta teratology. In: SJ Roberts (Ed), Veterinary Obstetrics and Genital Diseases (Theriogenology), Edwards Brothers, Michigan. pp. 38-92

Rubes J, Musilova P, Borkovec L, Borkovcova Z, Svecova D \& Urbanova J (1996). A new Robertsonian translocation in cattle, rob $(16 ; 20)$. Hereditas 124: 275-279

Sambrook J, Fritsch E F \& Maniatis T (1989). Molecular cloning: A laboratory manual. Second Edition. New York: Cold-Spring Harbor

Seabright M (1971). A rapid banding technique for human chromosomes. Lancet 2: 971-972

Seguin B E, Zhang T Q, Lance C B, Alvin F W \& Ruth G R (2000). Cytogenetic survey of Holstein bulls at a commercial artificial insemination company to determine prevalence of bulls with centric fusion and chimeric anomalies. Journal of The American Veterinary Medical Association 216: 65-67

Wathes D C (1992). Embryonic mortality and the uterine environment. Journal of Endocrinology 134: 321-325 